\title{
Praktik Media Relations Humas Pemerintah Kabupaten Tanjung Jabung Barat
}

\author{
Eriansyah \\ Humas Setda Kabupaten Tanjung Jabung Barat-Jambi
}

\begin{abstract}
The importance of media relations for an organization can not be separated from the "power" that the mass media are not only able todeliver a message to many audiences, but more than that, the basic concept ofthe media as his stretcher has a function to educate, influence, supervise, inform, entertain, mobilize, and so on. From this strategic media has the potential to provide understanding, raise awareness, change attitudes, opinions, and behaviors as goalsto betar get edinstitutions. However, it does not mean the media relations officer saw the mass media as a tool. Similarly for the media, new sagencies are resources that never dried to be explored. In other words, there isa symbiotic mutualism up between the two that eventually gave birth to a positive image.
\end{abstract}

Keywords: practice, government public relations, media relations, image

\section{Pendahuluan}

Keberadaan unit kehumasan di sebuah lembaga atau instansi pemerintah merupakan keharusan secara fungsional dan operasional dalam upaya menyebarluaskan atau untuk mempublikasikan kegiatan atau aktivitas instansi bersangkutan yang ditujukan baik hubungan masyarakat ke dalam maupun masyarakat di luar pada umumnya. Untuk memperlancar proses penyebaran informasi kepada publik, pemerintah dibantu media massa. Hal ini dilakukan di samping media mempunyai kekuatan menyampaikan informasi secara cepat, media juga mampu mengkonstruksi sebuah informasi. Asumsi dasar inilah yang mendorong pemerintah melakukan kerjasama dengan media.

Mengelola relasi yang baik dengan media menjadi sangat penting untuk menunjang kegiatan humas. Bahkan di banyak organisasi, ukuran keberhasilan kegiatan humas seringkali didasarkan pada jumlah pemberitaan yang disiarkan media massa. Kerjasama dan hubungan yang baik dengan media harus dilakukan secara profesional dan terukur, hal ini untuk menjaga masing-maing pihak agar tidak terjadi kesalahpahaman yang berujung pada ketidakseimbangan informasi. Terkadang informasi yang disampaikan media tidak sesuai dengan apa yang diharapkan organisasi/pemerintah, kondisi ini tentu akan merugikan dan berdampak pada citra negatif. Di era keterbukaan pers seperti saat ini, jarang sekali ada pemberitaan pers yang mengangkat keberhasilan pemerintah. Dari penjelasan tersebut mengindikasikan bahwa media massa lebih senang mengangkat penyimpangan, kesalahan maupun kekeliruan yang dilakukan oleh media massa karena lebih memiliki nilai berita (news value) untuk dijual bahkan ada anekdot menyebutkan bad news is good news and good news is bad news. 
Hubungan yang baik yang terbangun tentu akan menguntungkan bagi pemerintah, hal ini disebabkan pemerintah merupakan organisasi publik yang segala sesuatunya bersentuhan dengan publik, sehingga apa yang dilakukan pemerintah, publik juga harus mengetahuinya. Peran agenda setting media massa dalam membentuk agenda dan opini publik digambarkan oleh Walter Lippmann sebagai pseudoenvironment atau lingkungan palsu, artinya media massa lebih sederhana menyusun realita yang kompleks sehingga apa yang apa yang masyarakat ketahui tentang realita merupakan hasil dari penjagaan gerbang oleh media (Lippmann dalam Littlejohn dan Foss, 2011: 415-416). Untuk itulah dibutuhkan peran media dalam menyampaikan informasi tersebut, di samping itu untuk memperbaiki citra pemerintah yang cenderung negatif di mata publik. Hubungan baik dengan media tentu akan membatu memperbaiki citra pemerintah yang terlanjur apatis dimaknai oleh masyarakat.

Hubungan yang bersinergi antara media (media relations)dengan organisasi merupakan solusi yang perlu ditingkatkan sampai saat ini masih untuk kelancaran publikasi maupun penyebarluasan informasi organisasi dengan publiknya. Dengan kata lain media relationsmerupakan usaha untuk mencapai publikasi atau penyampaian informasi yang optimal terhadap pesan atau informasi humas dalam rangka menciptakan pengetahuan dan pemahaman bagi khalayak dari organisasi atau perusahaan yang bersangkutan (Jefkins, 1992:98).

Media massa dalam aktivitas humas dinilai memiliki kekuatan untuk mempengaruhi opini khalayak. Pesan atau informasi yang disampaikan humas melalui media massa membantu menciptakan opini khalayak terhadap organisasi. Dapat disadari bahwa membangun media relations dengan humas pemerintah merupakan suatu keharusan yang perlu ditingkatkan guna memperlancar tujuan organisasi.

Untuk memperlancar proses interaksi positif dan penyebarluasan informasi mengenai publikasi pembangunan nasional pada media massa dibutuhkan hubungan yang harmonis dan saling menguntungkan antara organisasi dengan media massa (Ruslan, 2000:9697).

Belum optimalnya hubungan yang baik antara humas pemerintah dengan media, tentu akan menghambat lancarnya penyebaran informasi yang menjadi tanggung jawab organisasi. Baik itu menyangkut pemberitaan tentang program kerja, rencana pernbangunan, kebijakan maupun peraturan daerah yang dibuat oleh pemerintah. Terkadang informasi yang disampaikan oleh media massa tidak sesuai dari apa yang diharapkan pemerintah, hal ini tentu akan berdampak negatif terhadap pemberitaan yang disampaikan dan pesan yang disampaikan juga akan dimaknai berbeda oleh publik.

Tidak adanya persamaan persepsi terhadap informasi antara pemerintah dengan media massa cenderung membuat berita tersebut tidak berimbang, hal ini jelas membuat informasi tersebut juga berbeda dipahami oleh publik. Fakta inilah yang mendorong pemerintah perlu meningkatkan hubungan baik dengan media massa agar informasi yang disampaikan mempunyai maksud yang sesuai dengan apa yang diharapkan oleh pemerintah.

Bertitik tolak dari uraian di atas menarik untılk diteliti lebih mendalam mengenai bagaimana praktik media relations humas Pemkab Tanjung Jabung Barat Jambi. 


\section{Tinjaun Pustaka}

\section{a. Pemahaman Peran Public Relations}

Aktivitas public relations seharihari adalah menyelenggarakan komunikasi timbal balik (two way communications) antara perusahaan atau suatu lembaga dengan pihak publik yang bertujuan untuk menciptakan saling pengertian dan dukungan bagi tercapainya tujuan tertentu. Peranan pokok public relations atau humas jika dibandingkan dengan bidang profesi kewartawanan mempunyai perbedaan dalam menjalankan fungsi dan tugasnya. Wartawan dengan media massa dan public relations/humas, di satu pihak mempunyai persamaan memiliki kekuatan (powerof opinion) dalam membentuk opini publik dan di lain pihak media massa merupakan alat kontrol sosial, sedangkan public relations lebih menekankan fungsi untuk menggalang pengertian antara lembaga yang diwakilinya dengan publik yang menjadi target sasarannya (Ruslan, 2005:1).

Jika ditelaah fungsi dan kepentingan masing-masing pihak akan terlihat perbedaannya. Sebagai contoh, jika lembaga atau perusahaan dan tokoh masyarakat atau pejabat tinggi (public figur) sedang "bermasalah" dengan opini publiknya, maka bagi wartawan hal tersebut justru merupakan sesuatu untuk dijadikan sumber berita (make a resource news), apalagi menyangkut pemberitaan yang negatif, bila perlu didramatisasi atau di blow up sedemikian rupa agar menarik perhatian pembaca atau publik. Sedangkan bagi humas sendiri hal tersebut merupakan situasi yang tidak menguntungkan, bila perlu justru "ditutup-tutupi" dengan berbagai alasan untụk menutup saluran informasi (to kill the information technique) agar berita negatif tersebut tidak terekspos ke luar.
Dalam menjalankan tugas dan fungsinya, aparatur humas tidak dibenarkan dengan sengaja mengekspos atau mernaparkan hal yang negatif dari lembaga yang diwakilinya itu kepada pihak pers atau publik. sebaliknya, pihak humas harus berupaya keras menjaga citra lembaga (maintenance of good image) di mata publiknya.

Dalam pandangan Baskin dan Aronof (1992), seorang Public Relations Officer (PRO) perlu memahami komunikasi dalam konteks sebagai berikut:

1. Ketrampilan, yang berkaitan dengan kemampuan dasar PRO yaitu menulis dan berbicara. Selain itu juga perlu mengembangkan ketrampilan, melakukan riset, merumuskan rencana, mengevaluasi hasil dan ketrampilan dalam menggunakan teknologi komunikasi.

2. Tugas-tugas, yang berkaitan dengan tugas yang harus dijalankan oleh PRO misalnya pembuatan release, pembuatan majalah internal, laporan tahunan dan sebagainya.

3. Sistem komunikasi, yaitu suatu usaha yang sistematis untuk mengumpulkan informasi, membina hubungan dengan berbagai pihak sebagai cara untuk memperoleh masukan dan pandangan publik.

4. Sistem operasi, yang berkaitan dengan usaha untuk membangun sistem komunikasi dua arah.

Kegiatan komunikasi yang diadakan organisasi (PR) seharusnya di kelola dengan baik karena publik yang menjadi sasaran suatu organisasi amat kompleks, dan tugas yang harus dijalankan amat banyak. Salah satu hubungan dengan publik eksternal (di luar lembaga) yang perlu dikelola adalah hubungan. dengan media massa. Untuk membina hubungan baik dengan media massa perlu dipahami 
adanya perbedaan fungsi dan tugas antara PR dan pers agar tidak terjadi pertentangan dalam menjalankan fungsi dan tugasnya masing-masing. Fungsi PR kalau dibandingkan dengan fungsi pers maka akan terlihat bertolak-belakang. Ruslan (1999:159) mengatakan bahwa secara umum pers berfungsi memberikan informasi, penyebaran pengetahuan, unsur mendidik dan menghibur bagi pembacanya. Selain itu fungsi khusus pers adalah kemampuan untuk mempengaruhi opini masyarakat, melaksanakan sistem kepengawasan sosial. Hal tersebut memiliki pertentangan dengan fungsi PR yang justru berkaitan dengan publikasi bersifat positif, dengan penyebaran informasi atau pesan untuk meningkatkan pengenalan (awareness), mendidik, menciptakan citra dan opini masyarakat kepada sesuatu yang positif serta menghindarkan unsur-unsur pemberitaan atau publikasi yang bersifat negatif, sensasional, polemik atau kontroversial di masayarakat. Secara lebih jelas perbedaan antara fungsi PR dan pers/wartawan dapat dilihat pada gambar di bawah ini:

Gambar 1. fungsi PR dan pers/wartawan

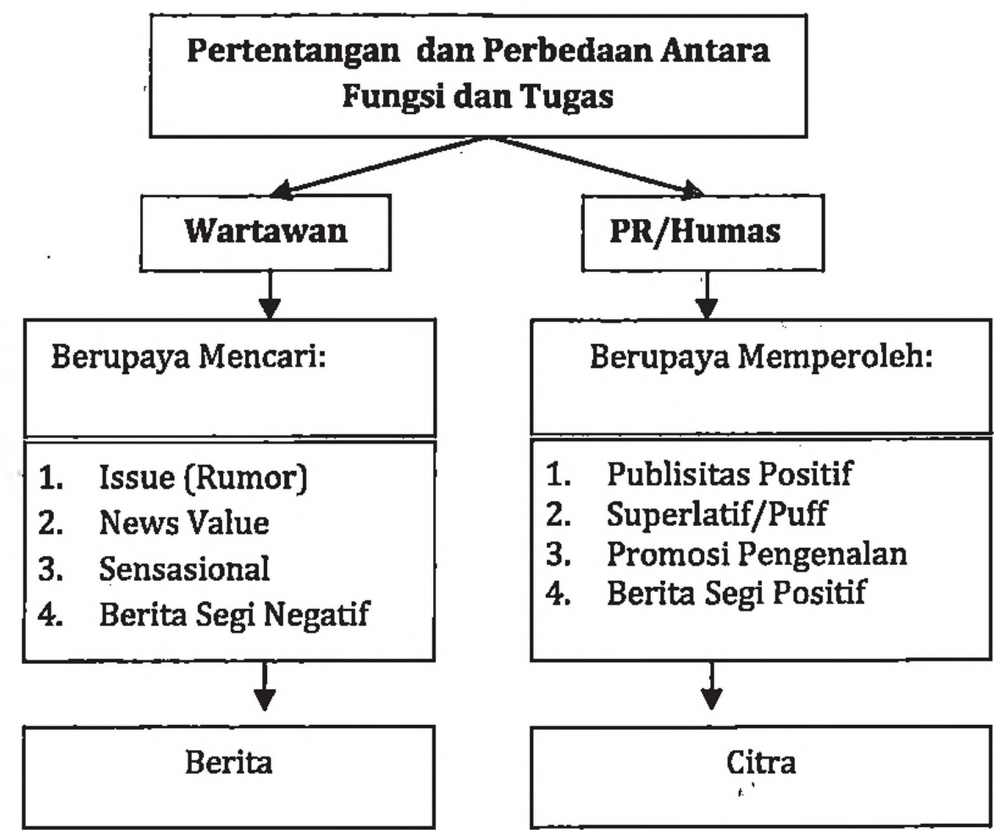

Sumber: Rosady Ruslan (1999: 161)

Membina hubungan dengan media massa perlu dilakukan karena peranan media massa sebagai media saluran (channel) dalam penyampaian pesan. Media massa memiliki kemampuan dalam penciptaan publikasi yang cukup tinggi baik yang bersifat stimultaneity effect (efek keserempakan), maupun efek mendramatisir, atau efek publisitas yang luar biasa pengaruhnya (influencing spheres) terhadap pembentukan opini publik (public opinion)' dalam jangka waktu relatif singkat, bersamaan dengan jangkauan jumlah pembaca yang tersebar di berbagai tempat atau kawasan (Ruslan, 1999:153). Hasil kerjasama yang baik ántara PR dan persdiharapkan akan tercipta suatu opini publik yang positif pula, yang dapat menguntungkan citra 
perusahaan atau organisasi dỉ mata publiknya.

\section{b. Humas dalam Praktik Media Relations}

Kerjasama yang dilakukan dengan media atas nama organisasi memungkinkan untuk kesadaran entitas yang akan diangkat serta kemampuan untuk membuat dampak dengan audiens yang dipilih. Hal ini memungkinkan akses ke kedua sasaran besar dan kecil dan membantu dalam membangun dukungan publik dan memobilisasi opini publik untuk sebuah organisasi, ini semua dilakukan melalui berbagai media dan dapat digunakan untuk mendorong komunikasi dua arah.

Menjalin dan menjaga hubungan dengan media merupakan cara yang efektif untuk membangun, menjaga, dan meningkatkan citra atau reputasi organisasi di mata stakeholder. Media relations sangat penting artinya sebagai wujud komunikasi dan mediasi antara suatu lembaga dengan publiknya. Di sisi lain, fungsi media relations yang berjalan baik sangat bermanfaat bagi aktivitas lembaga karena pihak media memberi perhatian pada isu-isu yang diperjuangkan.

Pentingnya media relations bagi sebuah organisasi tidak terlepas dari "kekuatan" media massa yang tidak hanya mampu menyampaikan pesan kepada banyak khalayak, namun lebih dari itu, media sebagaimana konsep dasar yang diusungnya memiliki fungsi mendidik, memengaruhi, menginformasikan, menghibur, memobilisasi, dan sebagainya. Dari sinilah media memiliki potensi strategis untuk memberi pengertian, membangkitkan kesadaran, mengubah sikap, pendapat, dan perilaku sebagaimana tujuan yang hendak disasar lembaga. Namun demikian, menurut Iriantara (2005), bukan berarti media relations officer melihat media massa sebagai alat. Keberadaan alat hanyalah ketika ia dibutuhkan, padahal bagi lembaga, media adalah mitra kerja. Demikian pula bagi media, lembaga adalah sumber informasi berita yang tidak pernah kering untuk dieksplorasi. Dengan kata lain, ada simbiosis mutualisme yang terbangun di antara keduanya. Media relations officer dapat menjalankan tugasnya karena ada media, sementara media pun memperoleh informasi yang diperlukan karena ada media relations officer yang memasok kebutuhan informasi tersebut.

Namun fakta yang terjadi di lapangan sering kali jauh berbeda dengan kondisi ideal yang digambarkan dalam teori dan konsep. Bahkan kondisi di lapangan sangat bertentangan dengan apa yang diharapkan. Hubungan antara humas dengan media massa sering kali kurang harmonis. Ada banyak kasus yang terjadi di masyarakat sebagai bukti hubungan yang kurang baik antara humas dengan media massa, seperti penelitian yang dilakukan oleh Pusat Studi Keamanan dan Perdamaian (PSKP) Universitas Gajah Mada (Masduki, 2009: 1). Hasil penelitian menunjukkan bahwa, hubungan antara public relatiosn di beberapa perusahaan migas yang ada di Sumatera Bagian Selatan (Sumbagsel) dengan wartawan sering kali berada pada kondisi tidak harmonis. Hal ini disebabkan perbedaan kepentingan di antara kedua profesi tersebut.

Public relations yang ada di perusahaan migas ini selalu menekankan pencitraan dalam setiap kegiatan yang mereka lakukan. Semua program yang dikerjakannya mulai dari kegiatan sosial, beriklan, sampai pembuatan berita maupun publisitas, dalam rangka membangun citra positif perusahaan migas ini. Karena penekanannya lebih kepada pencitraan positif perusahaan migas, maka tidak jarang public relations 
yang ada di perusahaan migas tersebut membuat "konstruksi . pesan" untuk susuatu informasi. Akibatnya, realitas semu lah yang disampaikan kepada khalayak. Pada tataran ini jelas sekali tanggung jawab untuk menyampaikan kebenaran kepada masyarakat tidak dapat dipenuhi.

Prinsip ini jelas membawa pada konsekuensi yang tidak dapat dihindarkan. Karena penekanan dari setiap pekerjaan yang dilakukan oleh public relations ini lebih mengacu pada pencitraan. Berbeda dengan public relations, bagi wartawan dan pekerja media lainnya, yang menjadi penekanan penting dari sebuah pemberitaan adalah keakuratan sebuah berita. Dalam pandangan mereka, masyarakat harus mendapatkan berita yang sesuai dengan apa yang sebenarnya terjadi. Artinya, untuk mencapai tujuarì organisasi yakni citra positif di mata publik pemerintah tidak perlu membuat informasi yang tidak benar, dengan menyampaikan informasi yang sebenarnya tidak perlu membohongi publik, di sini dibutuhkan strategi yang benar untuk meraih citra positi organisasi yakni dengan membangun kerjasama yang baik dengan media. Konstruksi pesan oleh media dengan keterampilan yang mereka miliki akan membantu membangun citra organisasi/pemerintah.

Dengan demikian, bisa dikatakan bahwa pemerintah mengunakan media massa sebagai medium penyampai pesan dan pencitraan kepada publik. Semakin banyak akses informasi yang didapat publik dari media massa berkaitan dengan program atau layanan yang diberikan oleh pemerintah, maka diharapkan semakin besar tingkat kepercayaan publik. Pada akhirnya publik akan memakai bahwa pekerjaan pemerintah yang dipublikasikan media betul-betul terlaksana.

\section{c. Konsep Ideal dalam Praktik Media Relations}

Dalam praktik hubungan pers, dikenal beberapa bentuk kegiatan yang melibatkanpers. Kegiatan ini dimaksudkan selain untuk menginformasikan aktivitas lembagaatau indvidu juga sebagai ajang peningkatan citra positif melalui media massa. Bentuk kegiatan hubungan pers adalah sebagai berikut:

1. Penyebaran siaran pers

Siaran pers biasanya disebut dengan nama Press Release. Biasanya hanya berupalembaran siaran berita yang dibagikan kepada para wartawan atau media massa. Kegiatan pembuatan dan penyebaran siaran pers ini merupakan kegiatan hubungan pers yang paling efisien. Siaran pers ini pun memiliki fungsi yang sama dengan media massa. Karena itu, sebuah siaran pers yang baik adalah siaran pers yang memiliki unsur-unsur jurnalistik sehingga menarik untuk dibaca. Dalam pelaksanaannya siaran pers bisa disiarkan sebelum atau setelah kegiatan dilaksanakan. Siaran pers pra kegiatan bisa bersifat informatif atau pemberitahuantentang bakal datangnya sebuah kegiatan yang dipandang dari sisi kehumasan sangat besar manfaatuya sebagai wahana publikasi sebuah kegiatan, baik itu kepanitiaan, maupun kegiatan lembaga dan individu. Selain dibutuhkan pada saat sebelum kegiatan, siaran pers pun penting setelah kegiatan berlangsung yang mengacu pada aktualitas waktu.

Hal-hal penting dalam penulisan siaran pers diantaranya adalah tulislah siaran pers dengan singkat dan padat yang mengandung $5 \mathrm{~W}+1 \mathrm{H}$ (What, Who, Where, Why, How). Siaran pers ditulis pada kertas 
yang berkop surat dengan mencantumkan nama pejabat yang berwenang atau fotokopi identitas individu serta tanda tangan yang benar-benar resmi. Dapat pula dilampirkan bahan-bahan tertulis yang berhubungan dengan masalah atau kegiatan yang diinformasikan untuk memperkaya siaran pers. Yang tidak kalah pentingnya adalah pengiriman siaran pers. Dapat melalui faximile atau melalui kurir bila melampirkan foto, atau cetakan berwarna dan kirimkan secepat mungkin pada wartawan yang dituju, serta konfirmasikan kembali lewat telepon apakah siaran pers sudah diterima atau belum.

2. Konferensi Pers atau Jumpa Pers

Konferensi pers atau jumpa pers merupakan suatu kegiatan hubungan pers yang paling dikenal yang dilakukan menjelang, menghadapi atau setelah teriadi peristiwa atau kegiatan penting atau besar. Penyelenggaraan jumpa pers ini bisa atas inisiatif lembaga humas, ataupun atas permintaan wartawan yang menginginkan informasi lebih lengkap tentang suatu peristiwa menarik yang terfadi di masyarakat. Kelebihan jumpa pers bila dibandingkan penyebaran siaran pers terletak pada aspek deskripsi atau tanya jawab. Dengan adanya forum antara wartawan dan penyelenggara jumpa pers memungkinkan wartawan makin kaya dengan informasi yang didapat sehingga wartawan dapat menulis berita tersebut lebih dari satu kolom, bahkan menjadi berita utama.

Ada pula yang menyebut jumpa pers dengan perss briefing. Sebenarnya kedua istilah itu sama, bedanya press briefing dilakukan secara rutin sedangkan jumpa pers tidak. Press briefing biasanya dilakukan pada acara-acara akbar yang berlangsung beberapa hari. Halhal penting yang perlu diperhatikan dalam penyelenggaraan jumpa pers diantaranya adalah jangan mengundang wartawan secara mendadak, menghargai waktu wartawan, jangan mengundurkan waktu jumpa pers, selenggarakan jumpa pers pagi hari dan di lokasi yang strategis, hindari jumpa pers pada hari libur, hadirkan orang yang mempunyai kredibilitas, jangan mengusir wartawan yang datang tidak diundang, sediakan data tertulis, hindari jumpa pers satu arah dan jawaban "no comment".

3. Kunjungan Pers

Kegiatan ini biasanya dilakukan oleh lembaga-lembaga yang besar baik swasta atau pemerintah. Terkadang disebut Press Tour, yaitu mengajak kalangan wartawan untuk berkunjung ke suatu lokasi, baik yang berada dilingkungannya maupun ketempat atau lokasi yang memiliki kaitan erat dengan kiprah lembaga tersebut.

Kegiatan kunjungan pers ini memang tidak murah, tetapi manfaat dari sisi kehumasan bisa jauh lebih besar ketimbang biaya yang dikeluarkan, Karena besarnya biaya ini, biasanya pihak humas hanya mengikutsertakan beberapa orang wartawan saja. Selain bermanfaat dari sisi humas, kunjungan pers ini amat potensial menjadi media marketing public relations.

4. Resepsi Pers

Resepsi pers merupakan salah satu bentuk kegiatan hubungan pers yang kerap kalidilakukan oleh banyak perusahaan besar dan pemerintah di negara-negara maju. Kegiatan ini merupakan acara untuk memperat 
hubungan antara humas dengan media massa. Resepsi pers sendiri adalah mengundang para insan media massa dalam sebuah resepsi yang khusus di selenggarakan untuk para pemburu berita. Acaranya bisa berupa makan siang bersama atau makan malam yang dilanjutkan dengan hiburan. Dalam menyelenggarakan resepsi pers harus di siapkan secara matang dengan menentukan waktu dan tempat serta media yang akan diundang. Juga harus menyiapkan pimpinan yang hadir dan kemungkinan menjawab pertanyaan diajukan oleh wartawan.

5 Peliputan Kegiatan

Dibanding kegiatan hubungan pers yang lain, peliputan kegiatan oleh pers merupakan kegiatan yang paling di kenal selain penyebaran siaran pers. Pers akan meliput acara yang mempunyai nilai jurnalistik yang memadai dan bersifat massal. Pihak penyelenggara dalam mengundang wartawan sebaiknya memperhatikan pemberian ID card, bahan-bahan informasi tertulis, memperlakukan wartawan dengan baik memberikan kemudahan, membantu wawancara dan jangan mempersulit wartawan.

\section{Wawancara Pers}

Merupakan kegiatan yang inisiatifnya datang dari media massa. Ada dua macamyaitu wawancara yang dipersiapkan dan wawancara spontan kegiatan ini merupakan bentuk hubungan dengan pers yang sudah biasa terjadi dan merupakan suatu rutinitas yang dilakukan oleh pers atau wartawan.

7. Lokakarya Pers

Yaitu mengundang wartawan atau pemimpin redaksi senior untuk berbagi pengalaman dan keterampilan kepada wartawan yang lebih muda pengalamannya. Kegiatan ini inisiatif datang dari Humas. Kegiatan ini diselenggarakan agar wartawan mempunyai keterampilan yang lebih baik dalam menyajikan berita-berita Humas berdasarkan latihan dan keterampilan yang diberikan oleh wartawan yang lebih senior (Abdullah, 2000:80-101).

\section{d. Konstruksi Informasi Melalui Media Relations}

Saat ini pemerintah telah memiliki kapasitas untuk menyampaikan informasi secara langsung. Kembalinya Departemen Penerangan dengan kemasan baru, kehadiran beragam situs resmi instansi pemerintah yang telah menghabiskan anggaran miliaran rupiah, kehadiran puluhan media massa internal pemerintah serta beragam jurnal menunjukkan kemampuan pemerintah menyediakan informasi yang dibutuhkan masyarakat.

Hampir seluruh instansi pemerintah memiliki kantor humas, divisi yang melakukan manajemen media massa, pembangun citra, jembatan pemerintah dengan masyarakat, serta penghubung pemerintah dengan pers. Kantor humas telah melakukan publikasi internal, memberdayakan kantor-kantor wilayah serta unit pelayanan teknis agar berperan sebagai outlet informasi. Pejabat humas pemerintah sebenarnya memiliki kemampuan bersaing dengan editor institusi swasta, khususnya dalam uji kompetensi. Tetapi, citra pegawai negeri sipil selama ini selalu dianggap korup dan terlalu santai. Kesan negatif pun telanjur menancap di benak masyarakat kita. Citra warisan yang telah berumur puluhan tahun yang semestinya diubah.

Sebelum bola reformasi bergulir, pemerintah memiliki image sebagai manipulator informasi. Bahkan setelah 
reformasi, image ini tidak banyak berubah. Pemerintah seolah dianggap 'musuh' yang harus dilawan. Dengan bergulirnya reformasi, pemerintah mentransformasikan diri agar menjadi pemerintahan yang bersih dan benar. Masyarakat telah memahami hak-haknya yang sekaligus juga menjadi kewajiban pemerintah. Dalam bidang pelayanan publik, masyarakat menuntut sistem pemerintahan yang bersih dan transparan. Masyarakat berhak atas akses informasi sebagaimana yaing telah dijamin oleh undang-undang, sebaliknya pemerintah wajib menjamin akses tersebut terjaga dan terkontrol agar tidak menimbulkan ekses negatif akibat eksploitasi pemberitaan yang bombastis.

Seiring dengan perubahan menuju tatanan baru demokrasi, reformasi di segala bidang termasụk di dalamnya reformasi performa pegawai negeri, sistem kehumasan serta sistem hubungan dengan media massa, maka memberdayakan divisi humas untuk mengubah citra aparat birokrasi agar lebih tanggap menyikapi fenomena masyarakat, sangat penting. Perkembangan teknologi informasi menuntut divisi humas dituntut lebih responsif terhadap keluhan masyarakat.

Seyogianya humas memang harus diberdayakan untuk menjaga nama baik aparat pemerintah serta menjalin kerja sama dengan pers agar tercipta pemberitaan yang berimbang, bermanfaat, 'dan bertanggung jawab. Eksistensi praktisi atau pejabat humas pemerintah sangat strategis, hal ini disebabkan diberlakukannya UU RI Nomor 14 Tahun 2008 tentang Keterbukaan Informasi Publik (KIP) pada 1 Mei 2010. Seluruh praktisi atau pejabat humas pemerintah dan satuan kerja pemerintah mulai desa, kecamatan, kabupaten/kota, provinsi hingga pusat, harus benar-benar mempersiapkan diri sehingga apa yang menjadi tujuan undang-undang tersebut dapat terwujud.

Hubungan antara humas dengan media bagaikan dua mata uang yang tidak bisa dipisahkan satu sama lain. Humas tanpa media akan pincang, begitu juga sebaliknya media taupa humas dia akan lumpuh. Hubungan antara humas dengan media tentunya harus dibangun diatas pondasi yang baik dan saling memahami eksistensi masing-masing.

Berkenaan dengan hubungan humas dengan pers, kedua hubungan tersebut sebagai suatu yang sama. Padahal keduanya memiliki perbedaan mendasar baik dari segi fungsi utama maupun perannya (Frank Jefkins, 1992).

Hubungan media dengan pers merupakan alat pendukung atau media kerjasama untuk kepentingan proses publikasi dan publisitas berbagai kegiatan program kerja untuk kelancaran aktivitas humas dengan pihak publik. Karena peranan hubungan media dan pers dalam kehumasan tersebut dapat sebagai saluran dalam penyampaian pesan maka upaya peningkatan pengenalan dan informasi atau pemberitaan dari pihak publikasi humas merupakan prioritas utama.

Dalam masyarakat modern, media mempunyai peran sangat penting. Media menjadi sumber informasi, hiburan dan edukasi dalam waktu yang bersamaan. Terlepas dari sifat elitis, media dapat dijadikan fasilitas aspirasi interaktif oleh masyarakat. Juga dapat dijadikan guru (transmodern teacher) yang kapasitasnya bahkan melebihi guru, dalam pengertian yang sebenarnya (Hartley, 1999; dalam Spiegel, 2000: 413). Kontribusi media begitu besar, dalam hal mendukung terselenggaranya pemerintah reformis kearah yang lebih demokratis, transparan serta sesuai dengan aturan yang ada.

Selain itu, aktivitas humas dan korelasinya dengan media dan press 
relation dalam hal teknik pembuatan produk-produk publikasi, informasi dan berita dalam bentuk press release, photo press, newsletter, menimbulkan konsekuensi keharusan praktisi humas menguasai teknik penulisan jurnalistik dan presentasi. Ditambah lagi tuntutan untuk mampu mengelola dan membina húbungan baik dengan para pemimpin redaksi, pengasuh, dan wartawan atau reporter dari berbagai media massa. Hal tersebut adalah suatu kegiatan khusus dari pihak public relations untuk melakukan komunikasi penyampaian pesan atau informasi tertentu mengenai aktivitas yang bersifat kelembagaan, perusahaan/instansi, produk dan hingga kegiatan yang bersifat individual lainnya yang perlu dipublikasikan melalui kerjasama dengan pihak pers atau media massa untuk menciptakan publisitas dan citra positif.

Eksistensi humas sebagai badan publik pada sebuah lembaga pemerintahan sangat strategis dalam membangun citra positif institusi, kepala daerah juga individunya. Jurnalistik kehumasan seperti press realese, yang di publikasi melalui media massa merupakan bentuk nyata dari kegiatannya. Adapun kegiatan lain seperti press gathering, press tour, press conference merupakan aḱtifitas positif dalam menjalin hubungan antara Pemeritah melalui humas dan media, menuju good governance.

Media massa dapat dikatakan sebagai saluran efektif, yang digunakan pemerintah untuk menjangkau dan bersentuhan langsung dengan khalayak mengenai opini yang beredar ditengah masyarakat, pada kepentingannya dalam mengambil sebuah kebijakan. Untuk itu maka dalam hal mempublikasikan sebuah informasi, diharapkan agar pemerintah dan media bisa bersinergi membangun kekompakan dengan tujuan bersama menciptakan bangsa yang aman, tenteram, nyaman serta sejahtera.

Karena tidak dapat kita pungkiri bahwa kebersamaan tersebut memberikan dampak positif bagi keberlangsungan hidup berbangsa dan bernegara. Sebagai contoh bahwa informasi berguna dalam meningkatkan kesejahteraan hidup seseorang adalah, dengan beredarnya berita yang berimbang maka akan tercipta suasana yang kondusif dan itu pasti berdampak pada perhatian para investor asing untuk berkarya di negara kita. Dengan semakin tingginya tingkat kepercayaan negara asing berinvestasi di negara kita maka stabilitas perekonomian akan tetap terjaga.

Realitas sosial adalah hasil konstruksi sosial dalam proses komunikasi tertentu. Membahas teori konstruksi sosial (social construction), tentu tidak bisa terlepaskan dari bangunan teoritik yang telah dikemukakan oleh Peter L. Berger dan Thomas Luckmann. Berawal dari istilah konstruktivisme, konstruksi realitas sosial terkenal sejak diperkenalkan oleh Peter L. Berger dan Thomas Luckman melalui bukunya yang berjudul The Social Construction of Reality: A Treatise in The Sociological of Knowledge tahun 1966. Menurut mereka, realitas sosial dikonstruksi melalui proses eksternalisasi, objektivasi dan internalisasi.

Konstruksi sosial tidak berlangsung dalam ruang hampa, namun sarat dengan kepentingan-kepentingan (Bungin, 2008: 192). Bagi kaum konstruktivisme, realitas (berita) itu hadir dalam keadaan subjektif. Realitas tercipta lewat konstruksi, sudut pandang dan ideologi wartawan. Secara singkat, manusialah yang membentuk imaji dunia. Sebuah teks dalam sebuah berita tidak dapat disamakan sebagai cerminan dari realitas, tetapi ia harus dipandang sebagai konstruksi atas realitas. 
Konstruksi realitas yang dibangun media menciptakan pengetahuan dan realitas sosial melalui interaksi simbolis dalam suatu kelompok sosial. Jadi, pengetahuan dan realitas muncul dari persepsi manusia. Realitas adalah hasil ciptaan manusia kreatif melalui kekuatan konstruksi sosial terhadap dunia sosial di sekelilingnya. Dan kekuatan utama yang sangat berperan dalam dunia sosial adalah media massa.

Keduanya berkaitan dengan apa yang dilakukan media yang melayani berbagaifungsi informasi. Teori ini menjelas kan saling berhubungannya tiga perangkat variable utama dan menentukan jenis efek tertentu sebagai hasil interaksi antara tiga variable tersebut. Hal tersebut diperkuat oleh teori ketergantungan komunikasi politik pada medi amassa (Littlejohn, 1996: 348) bahwa dalam sisitem politik terdapat interaksi yangsaling berkaitan satu sama lain antara sistem sosial yang terdapat strukstur sosial budaya,struktur politik, dan struktur ekonomi dengansistem media yang memiliki kekuatan danpengemasan daya tarik isi berita, strukturdan fungsi.

Kedua sistem tersebut menjadi ketertarikan dan kebutuhan khalayak yang konsekuensinya akan memengaruhi faktor kognitif (pemikiran), afektif (perasaan) dan behavioral (perilaku). Kemudian kekuatan media massa juga didukung dan dimiliki pemilik modal, seperti pendapat Altschull (1985) bahwa dalam semua sistem pers media berita mewakili pihak yang menjalankan kekuasaan politik dan ekonomi.

Surat kabar, majalah dan outlet penyiaran bukanlah aktor independen ,meski mereka mempunyai potensi untuk menjalankan kekuasaan independen, isiberita selalu menunjukkan kepentingan dari orang-orang yang membiayai pers, dan semua sistem pers didasarkan pada kepercayaan ekpresi bebas, walaupun didefinisikan dengan cara yang berbeda. Sehingga Altschull menyimpulkan, "Sejarahpers menunjukkan bahwa surat kabar danvariasi model cenderung mementingkankepentingan pemilik, sedangkan pada saat yang sama melanggengkan kesan bahwapers adalah untuk melayani penggunakepentingan berita.

Media merupakan sarana yang sangat efektif dalam mempengaruhi opini masyarakat. Media diibaratkan sebuah jarum hipodermik mempunyai efek langsung"disuntikkan" kedalam ketidak sadaran audience. (Jason dan Ane Hill, 1997). Berbagai perilaku yang diperlihatkan televis memberikan rangsangan masyarakat untuk menirunya.

Dalam masyarakat modern, media mempunyai peran sangat penting. Ia menjadi sumber informasi, hiburan dan edukasi dalam waktu yang bersamaan. Terlepas dari sifat elitis, media dapat dijadikan fasilitas aspirasi interaktif oleh masyarakat. Juga dapat dijadikan guru (transmodern teacher) yang kapasitasnya bahkan melebihi guru, dalam pengertian yang sebenarnya (Hartley, 1999; dalam Spiegel, 2000: 413). Kontribusi media begitu besar, dalam hal mendukung terselenggaranya pemerintah reformis kearah yang lebih demokratis, transparan serta sesuai dengan aturan yang ada.Media juga telah mampu merasuki dunia politik dimana aktor-aktor politik memanfaatkan media untuk mencari dukungan masyarakat dalam pembentukan citra dan opini publik.

Tidak dipungkiri lagi perkembangan media massa semakin pesat, baik cetak maupun elektronik mengalami pertumbuhan yang luar biasa. Indikasinya, media massa mengalami kenaikkan dari tahun ketahun. Industri media massa pun ikut terdongkrak dan melahirkan konglomerasi media yang 
Jurnal komunikasi, Volume 9, Nomor 2, April 2015

menguasi beberapa segmentasi media. Tak heran lagi, dominasi para pengusaha semakin kokoh menancapkan diri sebagai kélompok pemilik modal sekaligus menguasai pencitraan media massa.

Pada dasarnya informasi yang disampaikan oleh media massa merupakan mantra yang ampuh dalam mempengaruhi opini publik dan merekonstruksi tatanan kehidupan social masyarakat, media massa juga menjadi sebuah kekuatan baru dalam perubahan masyarakat (new power social change), karena informasi bukan sekedar "tontonan" tetapi juga meruapakan sebuah "tuntunan" bagi para pemikmatnya. Di era yang serba canggih ini masyarakat seperti mendapatkan roh baru bagi eksistensinya dalam kehidupan

karena media massa telah mengkonstruksi pola pikir dan gaya hidup.

digunakan dalam menyampaikan informasi kepada khalayak banyak. Dengan media massa orang dapat menyebarluaskan sesuatu. Ini merupakan kekuatan tersendiri yang dibutuhkan oleh bermacam-macam kepentingan. Melalui media massa orang melakukan pengendalian atau kontrol terhadap suatu perkembangan. Ciri khas dari media massa adalah memiliki kemampuan untuk memikat perhatian khalayak secara serempak (simultaneous) dan serentak (instantaneous).

Secara sederhana, bila digambarkan arus komunikasi dalam praktik Media Relations seperti berikut ini (Iriantara, $2005: 31$ ).

Gambar 2. Arus komunikasi dalam praktik Media Relations

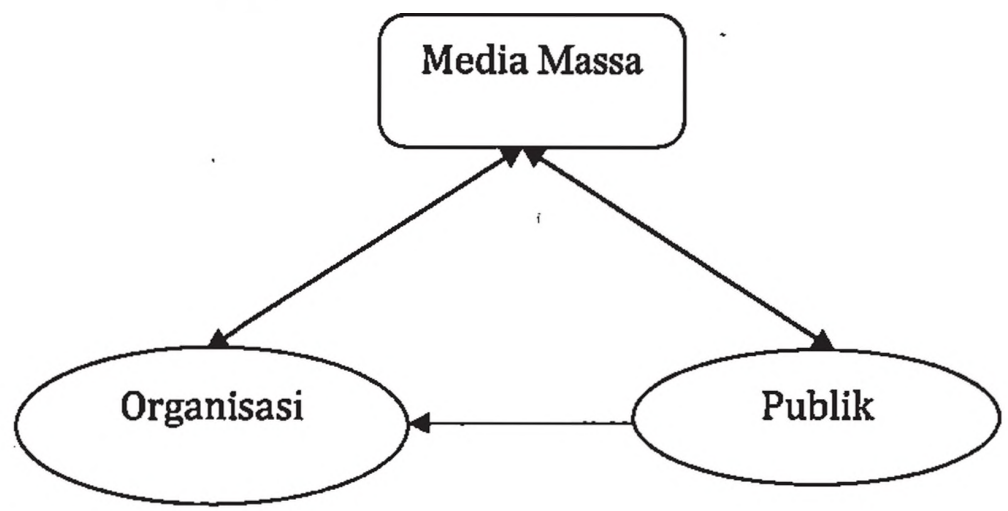

Gambar tersebut menunjukakn, organisasi menyampaikan informasi, gagasan atau citra melalui media massa kepada publik. sedangkan publik, bisa menyampaikan aspirasi, harapan, keinginan, atau informasi melalui media massa maupun pada organisasi. Namun publik juga bisa menyampaikan secara langsung melalui saluran komunikasi tersedia antara publik dan organisasi.

\section{Metodologi}

Penelitian ini menggunakan metode kualitatif, karena metode ini menurut peneliti sangat relevan untuk menggambarkan hasil temuan penelitian yang menyangkut hubungan humas pemerintah dengan media. Selain itu, metode kualitatif juga sebagai dasar untuk memperoleh gambaran mengenai objek penelitian serta untuk mengembangkan pengertian, konsep-konsep yang pada akhirnya menjadi sebuah teori. Pendekatan kualitatif bertujuan untuk menjelaskan fenomena dengan sedalamdalamnya melalui pengumpulan data sedalam-dalamnya.

Dalam penelitian ini, untuk menganalisis data yang diperoleh adalah dengan menggunakan studi kasus. 
4. Hasil dan Pembahasan

a. Pemahaman Aparatur Humas Pemkab Tanjung Jabung Barat terhadap Media Relations

Di era keterbukaan informasi publik saat ini, humasnya dituntut untuk lebih terbuka dalam menyampaikan informasi kepada publik sarta melakukan komunikasi kepada pihak internal maupun pihak eksternal. Transisi demokrasi di Indonesia yang terjadi pada kurun waktu beberapa tahun ini adalah sebuah paradigma dalam penyelenggaraan pemerintahan yang semula cenderung tertutup menjadi lebih transparan sehingga akses partisipasi publik berkembang semakin dinamis. Dalam konsep negara hukum yang demokratis salah satu ciri pokoknya adanya pengakuan dan penghormatan terhadap hak asasi manusia. Hak ini mengandung makna hak atas kebebasan memperoleh informasi publik mutlak menjamin sebagai bagian dari hak asasi manusia, dan kebebasan informasi publik tidak akan efektif apabila orang tidak memiliki akses terhadap informasi. Untuk menjangkau publik yang lebih luas humas membutuhkan media massa sebagai sarananya.

Ngurah, dkk (1996: 2) mengatakan bahwa wartawan harus dipahami sebagai publik juga dalam artian mereka adalah orang yang secara aktif mencari informasi dan memprosesnya. Berbeda dengan publik lain yang mencari dan memproses informasi, untuk kepentingannya sendiri, wartawan mencari informasi dan memprosesnya untuk disebarkan kepada khalayak pembaca media mereka. Berbeda dengan publik lain, yang mungkin terfokus perhatiannya ketika mencari informasi, para wartawan mencari informasi yang beragam. ${ }^{2}$ Sebagai pencari informasi yang harus bekerja berdasarkan prinsip-prinsip jurnalistik seperti mempertahankan objektifitas peliputan, melakukan peliputan yang berimbang wartawan mempunyai tanggung jawab untuk menyediakan informasi kepada publik sekaligus juga mereka berfungsi sebagai pemberi feedback kepada lembaga yang ada.

Irwiliyana Dewi mengatakan bahwa "dalam peliputannya, wartawan juga akan mencari informasi yang mungkin saja tidak menguntungkan organisasi. Sifat pekerjaan wartawan, melakukan penyeleksian berita misalnya, menjadikan ada berita-berita yang tak disiarkan baik karena prinsip-prinsip jurnalistik, kepentingan media tempat .wartawan itu bekerja, kode etik jurnalistik maupun kepentingan yang lebih luas, menuntut adanya kerja sama yang baik antara humas dan wartawan. Karena hubungan yang baik ini memberikan kemungkinan bagi humas untuk memahami segala peristiwa yang mungkin saja tidak disiarkan, tetapi diketahui oleh wartawan. Atau juga, jika suatu saat lembaga tempat humas bekerja mengalami hal-hal negatif, wartawan mungkin akan mencari informasi penyeimbang sehingga liputan tentang lembaga tersebut bisa lebih netral. Dalam hal ini hubungan baik dengan wartawan bukan saja bermanfaat untuk memperoleh liputan yang memadai sehingga visibilitas lembaga tetap terjaga, tetapi juga penting artinya untuk memperoleh perkembangan dalam masyarakat yang tidak terberitakan oleh media massa namun diketahui oleh para wartawan karena wartawan selalu didorong keinginan untuk mendapatkan

\footnotetext{
${ }^{1}$. Lihat http:// staff.uny.ac.id/.../AKTIVITAS\%20PUBLIC\%20REL ATIONS..., diakses 7 September 2014 pukul 19.23 wib
} 
fakta sebanyak-banyaknya dan seakurat mungkin"2.

Sebagaimana yang dilakukan oleh Humas Kabupaten Tanjung Jabung Barat. Untuk menjalin kerjasama yang baik humas dengan media massa masingmasing pihak saling memahami peran dan fungsinya masing-masing. Humas Pemkab Tanjung Jabung Barat juga menyadari bahwa media di samping merupakan saluran informasi bagi masyarakat juga sebagai alat kontrol sosial atas penyelenggaraan pemerintahan. Dari pemahaman tersebut jelas sekali humas sangat menyadari bahwa peran media sangat penting bagi humas untuk membangun kerjasama dengan media. Pemahaman inilah yang menjadi dasar bagi Humas Pemkab Tanjung Jabung Barat perlu menjalin kerjasama dengan media massa.

Dengan demikian dapat disimpulkan bahwa keterbukaan kepada para wartawan menjadi penting untuk menumbuhkan saling percaya antara humas dan wartawan. Agar kerjasama yang terjalin antara humas dengan media berjalan sebagaimana mestinya perlu adanya saling memahami kedudukan dan fungsinya masing-masing. Humas dan media massa atau pers tidak dapat dipisahkan satu sama lain. Keduanya saling memiliki ketergantungan dan membentuk sinergi yang positif. Humas sebagai sumber berita bagi media dituntut untuk lebih terbuka dan transparan dalam menyampaikan informasi. Untuk itulah keduanya saling menyadari bahwa mereka saling membutuhkan satu sama lain.

Menurut Rosady Ruslan (1999: 154), Press Relations merupakan suatu kegiatan khusus dari pihak public relations untuk melakukan komunikasi penyampaian pesan, atau informasi

2. Wawancara Irwiliyana Dewi Kepala Sub Bagian Informasi dan Publikasi Humas Pemerintah Kabupaten Tanjung Jabung Barat, 9 September 2014 pukul 11: 20 wib tertentu mengenai aktivitas bersifat kelembagaan, perusahaan/institusi, produk dan hingga kegiatan bersifat individual lainnya yang perlu dipublikasikan melalui kerjasama dengan pihak pers atau media massa sehingga akan tercipta suatu opini publik yang positif dan sekaligus memperoleh citra yang baik dari publik sebagai khalayak sasarannya.

Berdasarkan pemaparan di atas tentang hubungan humas dengan media jelas bahwa tujuan pokok press relations sebenarnya menciptakan pengetahuan dan pemahaman, menyebarkan informasi atau pesan demi citra yang positif di hadapan khalayak. Atas dasar inilah hubungan yang berlangsung antara pemerintah dengan media massa perlu dibangun dengan baik.

Jefkins (1996:100) berpendapat bahwa PR suatu perusahaan wajib mengetahui hal-hal tentang pers yaitu: (1), kebijaksanaan keredaksian, (2), frekuensi penerbitan , (3), tenggat terbit, (4) proses produksi, (5), daerah sirkulasi (6) khalayak pembaca dan (7) metode distribusi. Pemahaman tentang media juga dapat dilihat dari jenis media (audio visual, cetak, audio), lingkup peredarannya (media internasional, nasional, regional, lokal), orientasinya (media umum, khusus), kharakteristik wartawan dilihat dari bidang kerjanya (bidang politik, ekonomi, sosial budaya, dll).

Dari sekjan banyak yang perlu diketahui tentang pers, insan pers yang sering dikenal dengan nama wartawan perlu mendapat perhatian karena melalui insan humas akan sering berhubungan dalam kaitan menjalankan tugasnya masing-masing.

\section{b. Praktik Media Relations Humas Pemkab Tanjung Jabung Barat}

Pentingnya media relations bagi humas pemerintah tidak terlepas dari 
"kekuatan" media massa yang tidak hanya mampu menyampaikan pesan kepada banyak khalayak, namun lebih dari itu, media sebagaimana konsep dasar yang diusungnya memiliki fungsi mendidik, memengaruhi, mengawasi, menginformasikan, menghibur, memobilisasi, dan sebagainya. Dari sinilah media memiliki potensi strategis untuk memberi pengertian, membangkitkan kesadaran, mengubah sikap, pendapat, dan perilaku sebagaimana tujuan yang hendak disasar lembaga. Namun demikian, menurut Iriantara (2005), bujkan berarti media relations officer melihat media massa sebagai alat. Keberadaan alat hanyalah ketika ia dibutuhkan, padahal bagi lembaga, media adalah mitra kerja. Demikian pula bagi media, lembaga adalah sumber informasi berita yang tidak pernah kering untuk dieksplorasi. Dengan 'kata lain, ada simbiosis mutualisme yang terbangun di antara keduanya yang pada akhirnya melahirkan sebuah citra yang positif. Undang-undang Nomor 14 Tahun 2008 tentang Keterbukaan Informasi Publik mendorong setiap instansi pemerintah untuk memberikan dan menyampaikan informasi kepada publik, baik langsung maupun tidak langsung. Informasi yang bersifat langsung tidak membutuhkan media untuk menyampaikannya, sedangkan informasi yang tidak langsung sangat bergantung kepada media sebagai saluran informasi. Humas sebagai instansi yang menjadi sumber informasi pemerintah membutuhkan kerjasama dengan media untuk membantu mempublikasikan berbagai kegitan pemerintah. . Untuk mewujudkan hal tersebut dibutuhkan kerjasama antara humas dengan media salah satu kegiatannya adalah media relations. Kegiatan media relations yang dilakukan oleh humas Kabupaten lain pada dasarnya sama dengan yang dilakukan di humas Pemkab Tanjung
Jabung Barat. Yakni melakukan jumpa pers, penyebaran siaran pers, peliputan kegiatan, dan kunjungan pers. Di Kabupaten Tanjung Jabung Barat terdapat beberapa media massa yang menjadi mitra humas, baik itu media lokal maupun media nasional. Kerjasama ini dilakukan oleh humas untuk membantu humas dalam mempublikasikan berbagai informasi.

Membina hubungan dengan media massa perlu dilakukan karena peranan media massa sebagai media saluran (channel) dalam penyampaian pesan. Media massa memiliki kernampuan dalam penciptaan publikasi yang cukup tinggi baik yang bersifat stimultaneity effect (efek keserempakan), maupun efek mendramatisir, atau efek publisitas yang luar biasa pengaruhnya (influencing spheres) terhadap pembentukan opini publik (public opinion) dalam jangka waktu relatif singkat, bersamaan dengan jangkauan jumlah pembaca yang tersebar di berbagai tempat atau kawasan (Ruslan, 1999:153).

Dalam membina hubungan yang harmonis antara humas Pemerintah Kabupaten Tanjung Jabung Barat dengan media pada dasarnya mengacu pada sikap saling menghargai (mutual appreciation), saling pengertian (mutual understanding), saling mempercayai (mutual confidence) dan toleransi. Di samping itu humas Pemkab Tanjung Jabung Barat juga melakukan komunikasi secara interpersonal dengan media. Komunikasi interpersonal ini penting dilakukan untuk mewujudkan kerjasama yang baik. Adanya rasa persahabatan antara aparatur humas dengan media jelas akan mendorong saling memahamai satu sama lain sebagaimana yang diungkapkan oleh Irwiliyana Dewi yang merupakan Kepala Sub Bagian Informasi dan Publikasi humas Pemkab Tanjung Jabung Barat. Ia menjelaskan bahwa "untuk mewujudkan kerjasama yang baik dengan 
media, kami sering melakukan jumpa pers, misalnya menyangkut programprogram pemerintah atau ada kegiatan yang sifatnya strategis. Hal ini sangat penting agar informasi yang kami sạmpaikan tidak lari dari substansinya. Di samping itu juga kami salu menjalin komunikasi antara humas dengan media, baik itu sifatnya personal maupun tidak dan juga agar komunikasi yang terjalin mampu memberikan pemahaman kepada rekan-rekan media. Kami juga melakukan pers tour dengan beberapa rekan media dan sesekali cofee morning. Upaya ini jelas memberikan dampak positif terhadap keberlangsungan kerjasama yang baik namun tidak bertujuan membuat kehilangan peran dan fungsinya menyampailan informasi yang benar".3 Tidak dapat dipungkiri bahwa media memiliki kekuatan dalam mengkonstruksi sebuah informasi. Jika kersama yang terjalin tidak harmonis tidak menutup kemungkinan akan muncul tendensius dari pihak media. Menurut Ruslan (1999:158) hubungan yang baik dengan media massa tersebut dibangun melalui sụatu kejujuran, serta mau membantu untuk pelayanan pemberian sumber berita atau informasi yang diperlukan dalam suasana saling menghormati, dan adanya keterusterangan. Hubungan baik dengan media dapat tercapai apabila pihak PR menerapkan prinsip-prinsip membina hubungan yang harmonis yaitu:

1. Mutlak adanya kejujuran, dan keterusterangan.

2. Memberikan pelayanan yang sebaikbaiknya kepada pers /media.

3. Jangan meminta-minta atau mengemis kepada pers/wartawan, misalnya agar press release bisa dimuat padahal nilai beritanya tidak ada sama sekali.

3. Wawancara Irwiliyana Dewi Kepala Sub Bagian Informasi dan Publikasi Humas Pemerintah Kabupaten Tanjung Jabung Barat, 9 September 2014 pukul 11: 20 wib
4. Jangan coba-coba minta untuk menutup saluran informasi, misalnya pihak humas mengucapkan, no comment, tidak tahu, tolong jangan dimuat, hingga off the record kepada pihak pers. Kalau saluran informasi tersebut ditutup, maka pers akan mencari informasi tidak resmi, yang kebenarannya tidak dapat lagi terkontrol oleh pihak humasnya.

5. Jangan terlalu membanjiri media dengan segala macam publisitas yang tidak jelas tujuan atau sasaran yang hendak dicapai.

6. Selalu meng-updated setiap daftar nama reporter, tugas peliputannya, alamat dan telepon redaksi dan sebagainya, agar dalam kerjasama itu saling mengenal dengan baik antar kedua belah pihak dalam upaya membangun "good press relationship" tersebut.

Berdasarkan pemaparan di atas dapat disimpulkan bahwa untuk mewujudkan kerjasama yang baik didasari dengan adanya saling pengertian dan saling memahami posisi masing-masing. Merangkul semua media yang ada merupakan kebijakan yang harus diambil oleh humas pemerintah tentunya dengan proporsi yang mereka miliki. Hengky yang merupakan wartawan Jambi Independen mengatakan bahwa "dalam menjalin kerjasama dengan humas, media tidak media tidak merasa diintervensi dalam mengangkat sebuah berita, pihak media juga melakukan konfirmasi kepada humas jika ada opini yang berkembang di tengah masyarakat menyangkut hal-hal negatif yang dilakukan pemerintah. Sejauh ini hubungan media dengan humas berjalan dengan baik. Dan yang paling penting adalah memahami kedudukan masingmasing. Memang ada sentimen dari teman-teman media lainnya terutama 
media lokal, mereka merasa dibedabedakan oleh humas, tetapi menurut saya apa yang dilakukan humas berdasarkan proporsi media tersebut". 4

Pemaparan di atas menunjukkan adanya segmentasi dalam membangun hubungan antara humas dengan media. Humas melihat gret yang dimiliki media tersebut, artinya cakupan yang dimiliki media tersebut tidak sarna dengan cakupan yang dimiliki media lain. Jambi Independent dan Jambi Ekspress misalnya memiliki polah yang besar dan memiliki cakupan seluruh kabupaten di Provinsi Jambi, sedangkan media lokal dengan oplah dan cakupannya hanya mampu memenuhi pembaca di dalam kabupaten. Hal inilah yang mendasari humas melakukan segmentasi dan dengan nilai kontrak yang berbeda dengan media lain.

Belum optimalnya komunikasi dengan publik internal seperti antar sesama SKPD sering kali membuat pemberitaan berdampak pada pemerintah daerah. Hal ini justru menimbulkan citra yang buruk bagi pemerintah daerah. Media sering dianggap mencari-cari kesalahan. Pemahaman SKPD ini justru merugikan pemerintah yang menghendaki adanya publikasi di setiap SKPD. Seperti yang diungkap Dadang salah satu staf humas Kabupaten Tanjung Jabung Barat bahwa" ada SKPD yang terkadang takut dengan wartawan, padahal sebelumnya rekan wartawan telah melakukan konfirmasi kepada SKPD terkait tentang apa yang akan dipublis. Tidak adanya jawaban dan konfirmasi dari SKPD tersebut akhirnya muncul anggapan oleh media bahwa ada sesuatu yang ditutuptutupi oleh SKPD tersebut".5

\footnotetext{
4. Wawancara Hengky Wartawan Jambi Independent Group Jawa Pos, 8 September 2014 pukul 9:34 wib

5. Wawancara Dadang, 10 September 2014 pukul 10:00 wib
}

Berdasarkan pemaparan di atas dapat disimpulkan bahwa humas Sekretariat sebagai induk informasi di daerah seharusnya melakukan koordinasi yang terintegrasi agar terjalin komunikasi yang baik. Ketidaktahuan SKPD tentang adanya hubungan yang dijalin dengan media (media relations) membuat sebagian SKPD menjaga jarak dengan media. Untuk itulah perlunya melakukan koordinasi dengan SKPD yang lain agar apa yang menjadi tujuan lembaga pemerintah dapat berjalan dengan baik.

\section{Penutup}

Transisi demokrasi di Indonesia yang terjadi pada kurun waktu beberapa tahun ini adalah sebuah paradigma dalam penyelenggaraan pemerintahan yang semula cenderung tertutup menjadi lebih transparan sehingga akses partisipasi publik berkembang semakin dinamis. Dalam konsep negara hukum yang demokratis salah satu ciri pokoknya adanya pengakuan dan penghormatan terhadap hak asasi manusia. Hak ini mengandung makna hak atas kebebasan memperoleh informasi publik mutlak menjamin sebagai bagian dari hak asasi manusia, dan kebebasan informasi publik tidak akan efektif apabila orang tidak memiliki akses terhadap informasi.

Pentingnya media relations bagi humas pemerintah tidak terlepas dari "kekuatan" media massa yang tidak hanya mampı menyampaikañ pesan kepaùa banyak khalayak, namun lebih dari iłu, media sebagaimana konsep dasar yang diusungnya memiliki fungsi mendidik, memengaruhi, mengawasi, menginformasikan, menghibur, memobilisasi, dan sebagainya. Dari sinilah media memiliki potensi strategis untuk memberi pengertian, membangkitkan kesadaran, mengubah sikap, pendapat, dan perilaku sebagaimana tujuan yang hendak disasar lembaga. humas dengan madia saling 
memahami peran dan fungsinya masingmasing. Melalui hubungan tersebut juga, pemerintah mengharapkan berita yang berimbang dan tidak terkesan mernojokkan. Atas dasar inilah hubungan yang berlangsung antara pemerintah dengan media massa dapat berjalan dengan baik. Sebagai saluran komunikasi, media massa memiliki karakteristik tersendiri dibandingkan media lainnya.

Menjalin dan menjaga hubungan dengan media merupakan cara yang efektif untuk membangun, menjaga, dan meningkatkan citra atau reputasi organisasi di mata stakeholder. Media relations sangat penting artinya sebagai wujud komunikasi dan mediasi antara suatu lembaga dengan publiknya. Di sisi lain, fungsi media relations yang berjalan baik sangat bermanfaat bagi aktivitas humas karena pihak media memberi perhatian pada isu-isu yang diperjuangkan.

\section{DAFTAR PUSTAKA}

Abdullah, Aceng, 2000, Press Relations Kiat Berhubungan Dengan Media Massa, Bandung: PT Remaja Rosdakarya.

Baskin, O. \& Aronof, 1992, Public Relations: the Profession and the Practice. Edisi ketiga. Dubuque, IA:Wm.C.Brown.

Bungin, Burhan, 2008, Konstruksi Sosial Media Massa, Jakarta : Kencana.

Foss, Karen A, Littlejohn, Stephen 'W, 2011, Teori Komunikasi/ Teories of Human Communications, Jakarta: Salemba Humanika.

Iriantara, Yosal, 2011, Media Relations: Konsep, Pendekatam, dan Praktik. Bandung: Simbiosa Rekatama Media.

Jefkins, Frank. 1996. Public Relations (terjemahan . Haris Munandar). Jakarta: Penerbit Erlangga.

Erlangga.
Nastiti, Alwi Dwi, 2012, Identitas Kelompok Disabilitas Dalam Media Konten Online, Skripsi Fisip UI.

Robert, K. Yin, 2002, Studi Kasus Desain dan Metode, Jakarta: PT. Raja Grafindo Persada.

Ruslan, Rosady, 1999, Manajemen Humas dan Manajemen Komunikasi, Jakarta: PT. Raja Grafindo Persada.

2000, Kiat dan Strategi Kampanye Public Relations, Jakarta: PT Raja Grafindo Persada.

2005, Manajemen Public Relations dan Media Komunikasi, Jakarta: PT. Raja Grafindo Persada.

Spiegel, M.R. 1996. Teori dan Soal-Soal Statistika, Jakarta: Erlangga. 